\title{
Is protein synthesis necessary for prostaglandin production by guinea-pig endometrium?*
}

\author{
S. C. Riley and N. L. Poyser \\ Department of Pharmacology, University of Edinburgh Medical School, 1 George Square, \\ Edinburgh EH8 9JZ, UK
}

\begin{abstract}
Summary. The outputs of prostaglandin (PG) F-2 $\alpha$, PGE-2 and 6-keto-PGF-1 $\alpha$ from Day-7 and Day-15 guinea-pig endometrium in culture were reduced by the inclusion of actinomycin $D$, cycloheximide and puromycin in the culture medium, with the output of PGF-2 $\alpha$ from Day-15 endometrium being particularly affected during the first $6 \mathrm{~h}$ of culture. The intrauterine administration of actinomycin D on Day 10 decreased the outputs of PGF- $2 \alpha$ and PGE-2, but not of 6-keto-PGF-1 $\alpha$, from Day-15 endometrium in culture without affecting PG output from Day-15 myometrium in culture. Actinomycin D, cycloheximide and puromycin did not reduce PG output when superfused over the Day-7 and Day-15 guinea-pig uterus in vitro for $20 \mathrm{~min}$, indicating that these compounds do not have a rapid inhibitory effect on endometrial PG synthesis. In fact, they tended to stimulate PG output during this 20 -min period, with cycloheximide having a pronounced effect on PGE-2 output.

The synthesis of secreted proteins, but not of cellular proteins, was greater by Day-15 than by Day-7 endometrium in culture. Actinomycin D, cycloheximide and puromycin inhibited the synthesis of secreted and cellular proteins by Day-7 and Day-15 endometrium in culture. Protein synthesis and PG synthesis in the endometrium were both inhibited to a greater extent by cycloheximide and puromycin than by actinomycin D. The intrauterine administration of actinomycin D on Day 10 reduced the syntheses of secreted and cellular proteins by Day-15 endometrium in culture. These findings indicate that the endometrial synthesis of PGs, particularly of PGF-2 $\alpha$ towards the end of the oestrous cycle, is dependent upon endometrial protein synthesis.
\end{abstract}

Keywords: guinea-pig; uterus; prostaglandins; protein synthesis

\section{Introduction}

In several non-primate mammalian species, prostaglandin (PG) F-2 $\alpha$ released from the uterus is responsible for regression of the corpora lutea in the ovary (see Horton \& Poyser, 1976; Poyser, 1981). In the guinea-pig, oestradiol acting on a progesterone-primed uterus stimulates endometrial PGF-2 $\alpha$ production (Blatchley \& Poyser, 1974; Poyser, 1983a, b). Oxytocin has no effect on uterine PG output in the non-pregnant guinea-pig (Poyser \& Brydon, 1983; Riley \& Poyser, 1987a). Increased oestradiol output from the ovary on Day 10 (Joshi et al., 1973) precedes increased PGF$2 \alpha$ output from the uterus on Day 11 (Blatchley et al., 1972; Earthy et al., 1975; Antonini et al., 1976 ) in the guinea-pig, indicating a cause and effect relationship. Since many actions of oestradiol on the uterus are mediated through increased protein synthesis (see Brenner \& West, 1975), the effects of protein synthesis inhibitors on the production of PGs by guinea-pig endometrium have been investigated. Three inhibitors of protein synthesis with different mechanisms of action were 
chosen, namely actinomycin D (a DNA-dependent RNA synthesis inhibitor), cycloheximide (an inhibitor of the elongation step of protein transcription), and puromycin (a releaser of nascent polypeptide chains before their synthesis is complete).

\section{Materials and Methods}

Virgin guinea-pigs weighing $650-950 \mathrm{~g}$ were examined daily and a vaginal smear was taken when the vagina was perforate. The first day of the cycle was taken as the day preceding the post-ovulatory influx of leucocytes when cornification was at a maximum. All guinea-pigs used had exhibited cycles of normal length. They were killed on Day 7 or Day 15 of the cycle by stunning and incising the neck. In Exp. 5, a blood sample was collected from the incised neck into a heparinized $(20 \mathrm{U} / \mathrm{ml})$ syringe, and was centrifuged at $2500 \mathrm{~g}$ for $15 \mathrm{~min}$. The plasma was withdrawn and stored at $-20^{\circ} \mathrm{C}$ before being assayed for progesterone.

The uterus from each guinea-pig was removed and, in Exps 1, 2, 4 and 5, the endometrium was dissected from the myometrium by cutting away $1 \times 2 \mathrm{~mm}$ pieces of endometrium with a pair of fine scissors, under aseptic conditions. Pieces of endometrium were placed on a raised platform in a Petri dish which contained $4 \mathrm{ml}$ Medium 199, plus Earle's salts, and supplemented with glutamine, amphotericin B and kanamycin (Ning et al., 1983). Some of the Petri dishes contained 'treatments', as detailed in the 'Results' section, and the Petri dishes were placed in modified Kilner jars (up to 9 dishes per jar). The endometrium was cultured for periods up to 12 or $24 \mathrm{~h}$ as described previously, and the tissue remains viable during culture (Ning et al., 1983; Ning \& Poyser, 1984). In Exp. 5, pieces of myometrium were cultured under identical conditions. At the end of culture, the amounts of endometrium and myometrium in each dish were accurately weighed. In Exp. 3, the two uterine horns were superfused, using the method of Poyser \& Brydon (1983).

\section{Radioimmunoassays}

PGF-2 $\alpha$, PGE-2 and 6-keto-PGF-1 $\alpha$ were measured using antibodies raised in this laboratory and whose crossreactivities have been reported elsewhere (Dighe et al., 1975; Poyser, 1980; Poyser \& Scott, 1980; Lytton \& Poyser, 1982; Poyser, 1987). The inter-assay and intra-assay coefficients of variation for the 3 assays were all $<10 \%$; the limits of detection were $30-40 \mathrm{pg}$ PG per assay tube for each assay.

Progesterone was measured as described previously (Poyser \& Horton, 1975), using an antibody raised in this laboratory and whose cross-reactivities have been reported previously (Poyser, 1983a, 1984). The intra-assay and inter-assay coefficients of variation were $10.8 \%$ and $10 \cdot 1 \%$, respectively. The detection limit was 30 pg progesterone per tube.

\section{Measurement of $\left[{ }^{3} \mathrm{H}\right.$ leucine incorporation into endometrial proteins}

Cellular proteins. The technique used was based on the method of Findlay et al. (1981). Endometrial tissue was weighed and washed 3 times with $1 \mathrm{ml}$ Medium 199 at $4^{\circ} \mathrm{C}$. The tissue was placed in $1 \mathrm{ml}$ lysis buffer $(8 \mathrm{M}$-urea, $1 \% \mathrm{v} / \mathrm{v}$ sodium dodecyl sulphate and $5 \% \mathrm{v} / \mathrm{v}$ mercaptoethanol), shaken, and incubated at $4^{\circ} \mathrm{C}$ overnight. Tissue proteins were then extracted by rapidly freezing and thawing (with mixing) the solution 3 times, followed by centrifugation at $1400 \mathrm{~g}$ for $15 \mathrm{~min}$. To four $200 \mu \mathrm{l}$ volumes of the supernatant were added $300 \mu \mathrm{l}$ saline $(9 \mathrm{~g} / \mathrm{l})$ containing bovine serum albumin $(0.1 \%)$ and L-leucine $(0.1 \%)$. Proteins were precipitated by adding $500 \mu \mathrm{l} 10 \% \mathrm{w} / \mathrm{v}$ trichloroacetic acid (TCA) and allowing to stand for $30 \mathrm{~min}$ at $4{ }^{\circ} \mathrm{C}$. Each solution was centrifuged at $1400 \mathrm{~g}$ for $15 \mathrm{~min}$ and the supernatant was discarded. The precipitate was washed with $500 \mu \mathrm{l} 5 \%$ TCA and centrifuged at $1400 \mathrm{~g}$ for $15 \mathrm{~min}$. The supernatant was removed and the precipitate was dissolved by incubating with $100 \mu \mathrm{l}$ formic acid for $30 \mathrm{~min}$ at room temperature. The amount of radioactivity in each sample was measured in a liquid scintillation counter.

Secreted proteins. The technique used was based on the method of Strinden \& Shapiro (1983). Each sample of culture medium was centrifuged at $1000 \mathrm{~g}$ for $10 \mathrm{~min}$. To four $200 \mu \mathrm{l}$ volumes of the supernatant were added $10 \mu \mathrm{l}$ of a solution containing bovine serum albumin $(20 \mathrm{mg} / \mathrm{ml})$ in saline $(9 \mathrm{~g} / \mathrm{l})$, and $300 \mu l 10 \%$ TCA. After incubation for $30 \mathrm{~min}$ at $4^{\circ} \mathrm{C}$, each sample was centrifuged at $1400 \mathrm{~g}$ for $15 \mathrm{~min}$. The supernatant was discarded, and the precipitate was washed with $300 \mu \mathrm{l} 5 \%$ TCA and centrifuged at $1400 \mathrm{~g}$ for $15 \mathrm{~min}$, a procedure which was repeated 3 times. Finally, the supernatant was discarded, and the precipitate was dissolved by incubating with $100 \mu \mathrm{l}$ formic acid for $30 \mathrm{~min}$ at room temperature. The amount of radioactivity present was measured in a liquid scintillation counter.

\section{Sources of material}

Medium 199 (plus Earle's salts), glutamine, amphotericin B and kanamycin were purchased from Flow Laboratories, Irvine, UK; sterile Petri dishes were purchased from Sterilin Ltd, Teddington, UK; actinomycin D, cycloheximide, puromycin, bovine serum albumin and L-leucine were purchaed from Sigma Chemical Co., Poole, Dorset, UK; $\left[{ }^{3} \mathrm{H}\right]$ leucine (sp. act. $160 \mathrm{Ci} / \mathrm{mmol}$ ) was purchased from Amersham International Ltd, Bucks, UK; 
Hypnorm was purchased from Crown Chemical Co. Ltd, Lamberhurst, UK; Hypnovel was purchased from Roche Products Ltd., Welwyn Garden City, UK.

\section{Statistical tests}

When two control samples were included in one Kilner jar, the two results obtained were averaged to give one control value. Changes in output of PGs with time in the tissue culture and superfusion experiments were analysed by Duncan's multiple range test. Differences between two groups were analysed by Student's $t$ test, which was used in a modified form if the variances were unequal by the variance ratio $F$ test, or by the paired $t$ test, as appropriate.

\section{Results}

\section{Experiment 1: effects of protein synthesis inhibitors on PG output from endometrium in culture}

Methods. Eighteen dishes of endometrium (12-20 mg/dish) were prepared from each uterus obtained from five Day-7 and five Day-15 guinea-pigs. Four dishes from each animal were untreated (controls), and 7 pairs of dishes were each treated with one of the following protein synthesis inhibitors at one of the concentrations: actinomycin $\mathrm{D}(1,10$ and $50 \mu \mathrm{g} / \mathrm{ml})$, cycloheximide $(10$ and $50 \mu \mathrm{g} / \mathrm{ml})$, puromycin $(10$ and $50 \mu \mathrm{g} / \mathrm{ml})$. These 18 dishes were equally divided between 2 Kilner jars such that each jar contained 2 control dishes and one dish from each pair of dishes. The endometrium was cultured for $24 \mathrm{~h}$ and the culture medium (containing the appropriate treatment) was changed every $6 \mathrm{~h}$. The samples of culture medium were stored at $-20^{\circ} \mathrm{C}$ before being assayed, without extraction, for PGF-2 $\alpha$, PGE-2 and 6-keto-PGF-1 $\alpha$.

Results. The basal outputs of PGF-2 $\alpha$, PGE-2 and 6-keto-PGF-1 $\alpha$ from Day-7 and Day-15 guinea-pig endometrium cultured for $24 \mathrm{~h}$ and sampled at 6-h intervals are shown in Fig. 1. The outputs of PGF-2 $\alpha$, PGE-2 and 6-keto-PGF- $1 \alpha$ from Day- 15 endometrium and of 6-keto-PGF-1 $\alpha$ from Day-7 endometrium significantly $(P<0.05)$ decreased with time. The output of PGF-2 $\alpha$ from Day-7 endometrium significantly $(P<0.05)$ increased up to $18 \mathrm{~h}$ and then tended to fall. The outputs of PGE-2 from Day-7 endometrium showed a similar trend, but the changes were not significant. PGF- $2 \alpha$ was the major PG released from Day-15 endometrium, with much lower quantities of 6-keto-PGF- $1 \alpha$ and PGE-2. Initially, 6-keto-PGF- $1 \alpha$ was the major PG released from Day-7 endometrium, with lower amounts of PGF-2 $\alpha$ and PGE-2. However, as 6-keto-PGF-1 $\alpha$ output declined and PGF- $2 \alpha$ output increased, PGF- $2 \alpha$ was the major PG released from Day-7 endometrium after 18 and $24 \mathrm{~h}$. The outputs of PGF-2 $\alpha$ and PGE-2 were significantly $(P<0.05)$ greater from Day-15 endometrium than from Day-7 endometrium at all times, whereas 6-ketoPGF-1 $\alpha$ output was significantly $(P<0.05)$ greater from Day-15 endometrium only after $12 \mathrm{~h}$ of culture.

Actinomycin D, cycloheximide and puromycin had no effect on the outputs of PGF-2 $\alpha$, PGE-2 and 6-keto-PGF-1 $\alpha$ from Day-7 endometrium during the first $6 \mathrm{~h}$ of culture, except that cycloheximide $(50 \mu \mathrm{g} / \mathrm{ml})$ significantly $(P<0.05)$ stimulated PGE-2 output. Actinomycin D $(10$ and $50 \mu \mathrm{g} / \mathrm{ml}$, but not $1 \mu \mathrm{g} / \mathrm{ml})$, cycloheximide $(10$ and $50 \mu \mathrm{g} / \mathrm{ml})$ and puromycin $(10$ and $50 \mu \mathrm{g} / \mathrm{ml})$ significantly $(P<0.05)$ inhibited PGF-2 $\alpha$ output from Day-7 endometrium after 12,18 and $24 \mathrm{~h}$ of culture (Fig. 2). Actinomycin D (10 and $50 \mu \mathrm{g} / \mathrm{ml}$, but not $1 \mu \mathrm{g} / \mathrm{ml})$, cycloheximide $(10 \mu \mathrm{g} / \mathrm{ml})$ and puromycin $(10$ and $50 \mu \mathrm{g} / \mathrm{ml})$ significantly $(P<0.05)$ inhibited PGE-2 output from Day-7 endometrium after 18 and $24 \mathrm{~h}$. PGE-2 output after $12 \mathrm{~h}$ was inhibited only by puromycin $(10 \mu \mathrm{g} / \mathrm{ml})$ and actinomycin $\mathrm{D}(50 \mu \mathrm{g} / \mathrm{ml})$. Actinomycin $\mathrm{D}$ (all 3 concentrations) and puromycin $(50 \mu \mathrm{g} / \mathrm{ml})$ had no effect on 6-keto-PGF- $1 \alpha$ output from Day-7 endometrium. Cycloheximide (10 and $50 \mu \mathrm{g} / \mathrm{ml})$ and puromycin $(10 \mu \mathrm{g} / \mathrm{ml})$ significantly $(P<0.05)$ inhibited 6-keto-PGF-1 $\alpha$ output from Day-7 endometrium after 12,18 and $24 \mathrm{~h}$ of culture (Fig. 2).

Actinomycin D ( $50 \mu \mathrm{g} / \mathrm{ml}$, but not 1 and $10 \mu \mathrm{g} / \mathrm{ml}$ except for $10 \mu \mathrm{g} / \mathrm{ml}$ after $24 \mathrm{~h})$, cycloheximide (10 and $50 \mu \mathrm{g} / \mathrm{ml}$ ) and puromycin $(10$ and $50 \mu \mathrm{g} / \mathrm{ml}$, but not $10 \mu \mathrm{g} / \mathrm{ml}$ after $6 \mathrm{~h}$ ) significantly $(P<0.05)$ reduced PGF-2 $\alpha$ output from Day-15 endometrium after $6,12,18$ and 24 h of culture (Fig. 3). None of the protein synthesis inhibitors affected the outputs of PGE-2 and 6-keto-PGF-1 $\alpha$ 


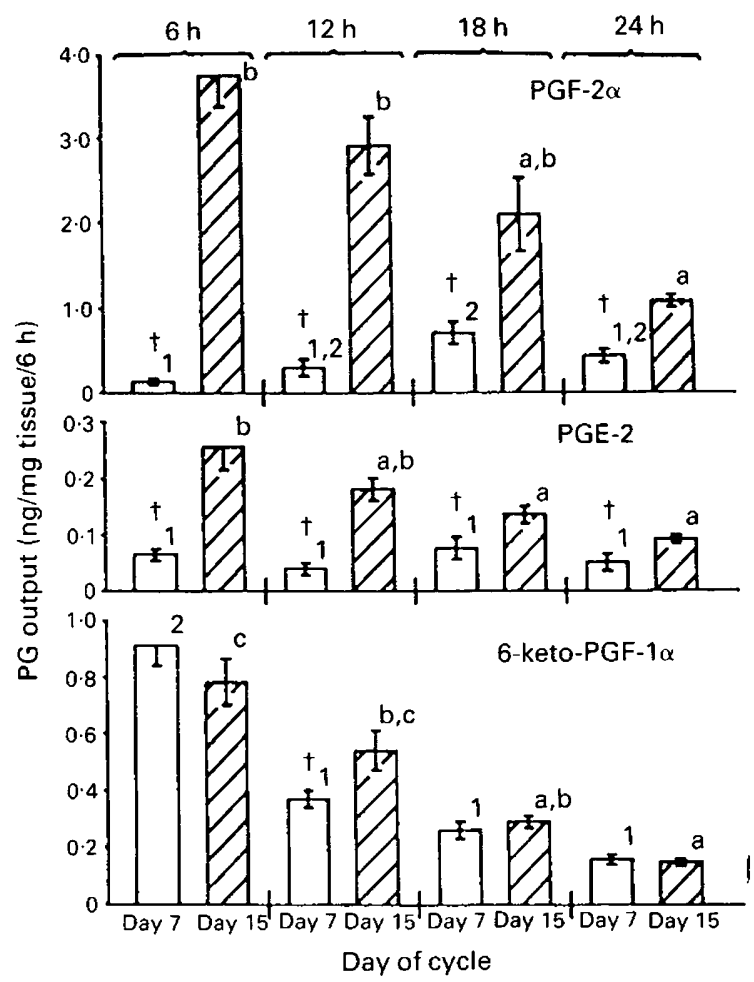

Fig. 1. Mean ( \pm s.e.m., $n=10$ ) outputs of prostaglandin (PG) F-2 $\alpha$, PGE-2 and 6-keto-PGF$1 \alpha$ from Day-7 and Day-15 guinea-pig endometrium cultured for $24 \mathrm{~h}$ and sampled every $6 \mathrm{~h}$. For any one PG on Day 7 , columns with the same number are not significantly $(P<0.05)$ different; for any one PG on Day 15, columns with the same letter are not significantly $(P<0.05)$ different. $\dagger$ Significantly $(P<0.05)$ lower than Day-15 value for the same $P G$ at the same time.

E-2 anc רd sam ynificar are no or the s

output from Day-15 endometrium after $6 \mathrm{~h}$, except for actinomycin $\mathrm{D}(50 \mu \mathrm{g} / \mathrm{ml})$ which significantly $(P<0.05)$ reduced PGE-2 and 6-keto-PGF- $1 \alpha$ output. Actinomycin D $(1$ and $10 \mu \mathrm{g} / \mathrm{ml})$ had no effect on the outputs of PGE-2 and 6-keto-PGF-1 $\alpha$ after 12, 18 and $24 \mathrm{~h}$ of culture, except for actinomycin D $(10 \mu \mathrm{g} / \mathrm{ml})$ which significantly $(P<0.05)$ reduced 6-keto-PGF-1 $\alpha$ output after $18 \mathrm{~h}$. The outputs of PGE-2 and 6-keto-PGF-1 $\alpha$ from Day-15 endometrium were significantly $(P<0.05)$ reduced after 12,18 and $24 \mathrm{~h}$ of culture by actinomycin D $(50 \mu \mathrm{g} / \mathrm{ml}$, except for 6-ketoPGF-1 $\alpha$ output after $24 \mathrm{~h})$, by puromycin $(10$ and $50 \mu \mathrm{g} / \mathrm{ml})$, and by cycloheximide $(10$ and $50 \mu \mathrm{g} /$ $\mathrm{ml}$, except for PGE-2 output after $24 \mathrm{~h}$ by both concentrations and for 6-keto-PGF-1 $\alpha$ output after $24 \mathrm{~h}$ by the lower concentration; Fig. 3 ).

Experiment 2: effects of protein synthesis inhibitors on $P G$ synthesizing capacity of endometrium in culture

Methods. Sixteen dishes of endometrium (12-20 mg/dish) were prepared from each uterus obtained from five Day-7 and five Day-15 guinea-pigs. Each set of 16 dishes was divided into 4 groups; one group of dishes was left untreated (controls) and the remaining 3 groups were treated with actinomycin $\mathrm{D}(50 \mu \mathrm{g} / \mathrm{ml})$, cycloheximide $(10 \mu \mathrm{g} / \mathrm{ml})$ or puromycin $(50 \mu \mathrm{g} / \mathrm{ml})$. The 16 dishes were divided equally between 2 Kilner jars such that each jar contained 2 dishes from each group. The endometrium was cultured for 6 or $12 \mathrm{~h}$. 

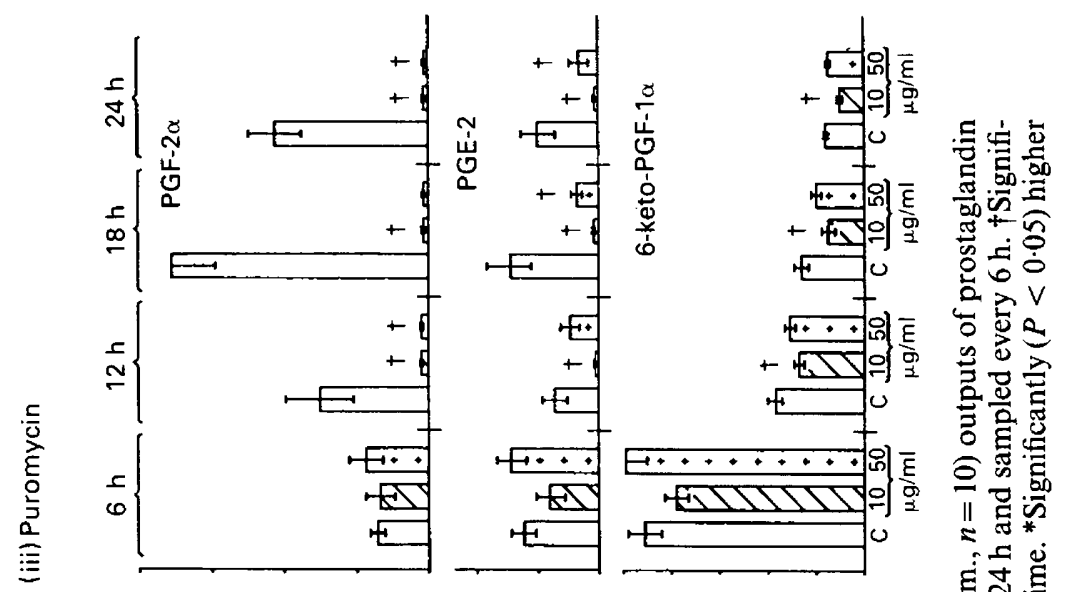

它象 总焉

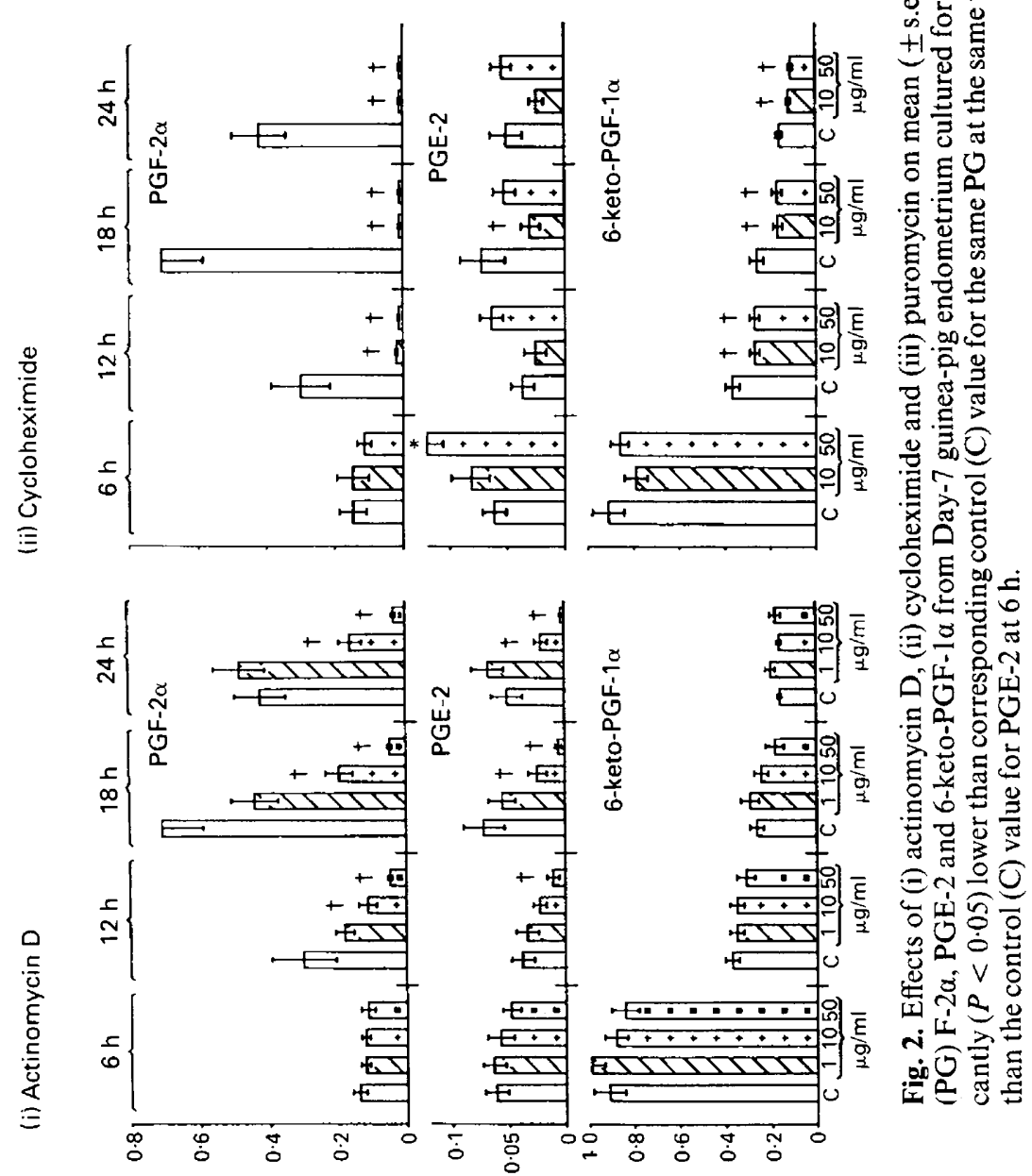

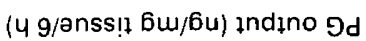






( 4 9/anss!? $6 u$ /6u $)$ Indłno $9 d$ 
Immediately after the jars were placed in the incubator, two amounts (12-20 $\mathrm{mg}$ ) of the remaining endometrium from each animal were weighed accurately and were each homogenized in $5 \mathrm{ml}$ Krebs' solution (for composition, see Mitchell et al., 1977) containing $2 \mu \mathrm{g}$ sodium arachidonate. Each homogenate was gassed with $95 \% \mathrm{O}_{2}$ and $5 \% \mathrm{CO}_{2}$, and was incubated at $37^{\circ} \mathrm{C}$ for $60 \mathrm{~min}$. PGs were extracted from the incubates as described previously (Poyser, 1983a) and were stored in $5 \mathrm{ml}$ ethyl acetate at $-20^{\circ} \mathrm{C}$.

After $6 \mathrm{~h}$ of incubation, one control dish and one dish containing each treatment was removed from each jar and the endometrium was processed as described above. The remaining 8 dishes were also removed; the culture medium was withdrawn and stored at $-20^{\circ} \mathrm{C}$, and was replaced with fresh medium containing the same concentrations of the same protein synthesis inhibitors. These dishes were placed back into the jars, the endometrium was cultured for a further $6 \mathrm{~h}$, and then the culture medium was withdrwn and stored at $-20^{\circ} \mathrm{C}$. The endometrium in each dish was processed as described above. The amounts of PGF-2 $\alpha$, PGE-2 and 6-keto-PGF-1 $\alpha$ in the samples of culture medium and in ethyl acetate extracts of the endometrial incubates were measured by radioimmunoassay.

Results. The amounts of PGF-2 $\alpha$, PGE-2 and 6-keto-PGF-1 $\alpha$ synthesized by homogenates of Day-7 and Day-15 endometrium were significantly $(P<0.05)$ greater after 6 and $12 \mathrm{~h}$ of culture than before culture started, except for PGF-2 $\alpha$ and PGE-2 production by Day-7 tissue at $6 \mathrm{~h}$. Actinomycin D $(50 \mu \mathrm{g} / \mathrm{ml})$, cycloheximide $(10 \mu \mathrm{g} / \mathrm{ml})$ and puromycin $(50 \mu \mathrm{g} / \mathrm{ml})$ significantly $(P<0.05)$ reduced the amounts of PGF-2 $\alpha$, PGE-2 and 6-keto-PGF- $1 \alpha$ synthesized by homogenates of Day- 7 and Day-15 endometrium after 6 and $12 \mathrm{~h}$ of culture (except for actinomycin D on 6-keto-PGF-1 $\alpha$ production by Day- 15 tissue after $6 \mathrm{~h}$; Table 1). Furthermore, the amounts of PGF-2 $\alpha$ and PGE-2 synthesized by homogenates of Day-7 and Day-15 guinea-pig endometrium following $12 \mathrm{~h}$ of culture in the presence of cycloheximide and puromycin were significantly $(P<0.05)$ lower than before culture $(0 \mathrm{~h}$; Table 1$)$. The outputs of PGF-2 $\alpha$, PGE-2 and 6-ketoPGF- $\mathrm{l} \alpha$ at 6 and $12 \mathrm{~h}$ from Day-7 and Day- 15 endometrium in culture and the effects of the protein synthesis inhibitors on PG output were essentially similar to the findings in Exp. 1 (compare Table 1 with Figs 2 and 3), indicating that Exps 1 and 2 are comparable.

Experiment 3: effects of protein synthesis inhibitors on PG output from and PG synthesizing ability of the superfused uterus

Methods. Each uterus from five Day-7 and five Day-15 guinea-pigs was separated into its 2 horns; each uterine horn was weighed, opened by 'cutting' longitudinally, and superfused with Krebs' solution $(5 \mathrm{ml} / \mathrm{min})$ at $37^{\circ} \mathrm{C}$ as described previously (Poyser \& Brydon, 1983). Each horn was superfused initially for a 'settling period' of $60 \mathrm{~min}$, and then samples of superfusate were collected for $10-\mathrm{min}$ periods over the next $80 \mathrm{~min}$ (i.e. 8 samples/uterine horn). During the collection of samples 4 and 5 , actinomycin $\mathrm{D}(50 \mu \mathrm{g} / \mathrm{ml})$ was added to the Krebs' solution superfusing one uterine horn from each animal. After collection, PGs were extracted from the samples of superfusate, as outlined previously (Poyser, 1987), and were stored in $10 \mathrm{ml}$ ethyl acetate at $-20^{\circ} \mathrm{C}$. Immediately after the period of superfusion, the endometrium and myometrium forming each uterus were separated, weighed, homogenized in $10 \mathrm{ml}$ Krebs' solution, incubated, and PGs were extracted and stored as in Exp. 2. The amounts of PGF-2 $\alpha$, PGE-2 and 6-keto-PGF-1 $\alpha$ present in all ethyl acetate extracts were measured by radioimmunoassay. This experiment was repeated twice more, substituting cycloheximide $(50 \mu \mathrm{g} / \mathrm{ml})$ or puromycin $(50 \mu \mathrm{g} / \mathrm{ml})$ for actinomycin D.

Results. The outputs of PGF-2 $\alpha$, PGE-2 and 6-keto-PGF-1 $\alpha$ from the Day-7 and Day- 15 uterus superfused in vitro were not reduced by actinomycin D, cycloheximide and puromycin (all at $50 \mu \mathrm{g} /$ $\mathrm{ml}$ ). In fact, stimulation of PG output was often observed (Tables 2 and 3). Actinomycin D significantly $(P<0.05)$ increased PGF-2 $\alpha$ output from the Day-7 uterus, PGE-2 output from the Day-15 
Table 1. Effects of actinomycin D (Actin. D; $50 \mu \mathrm{g} / \mathrm{ml}$ ), cycloheximide (Cyclohex.; $10 \mu \mathrm{g} / \mathrm{ml}$ ) and puromycin (Puromy.; $50 \mu \mathrm{g} / \mathrm{ml}$ ) on the mean ( \pm s.e.m., $n=10$ ) amounts of prostaglandin (PG) F-2 $\alpha$, PGE-2 and 6-keto-PGF-1 $\alpha$ (6-KF) synthesized by homogenates of (synthesizing ability) and released from Day7 and Day-15 guinea-pig endometrium immediately before culture $(0 \mathrm{~h}$; control PG synthesizing ability only), and after $6 \mathrm{~h}$ and $12 \mathrm{~h}$ of culture

\begin{tabular}{|c|c|c|c|c|c|}
\hline \multirow[b]{2}{*}{ Treatment } & \multicolumn{3}{|c|}{ PG synthesizing ability (ng/mg tissue) } & \multicolumn{2}{|c|}{ PG output (ng/mg tissue $/ 6 \mathrm{~h}$ ) } \\
\hline & $0 \mathrm{~h}$ & $6 \mathrm{~h}$ & $12 \mathrm{~h}$ & $6 \mathrm{~h}$ & $12 \mathrm{~h}$ \\
\hline
\end{tabular}

Day 7

\begin{tabular}{lcllll}
\hline PGF-2 $\alpha$ & & & & \\
Control & $0.11 \pm 0.01$ & $0.15 \pm 0.02$ & $0.23 \pm 0.05 \dagger$ & $0.13 \pm 0.02$ & $0.12 \pm 0.03$ \\
Actin. D & - & $0.09 \pm 0.01^{*}$ & $0.11 \pm 0.02^{*}$ & $0.12 \pm 0.01$ & $0.04 \pm 0.01^{*}$ \\
Cyclohex. & - & $0.09 \pm 0.01^{*}$ & $0.07 \pm 0.01^{*} \ddagger$ & $0.09 \pm 0.01^{*}$ & $0.03 \pm 0.01^{*}$ \\
Puromy. & - & $0.09 \pm 0.02^{*}$ & $0.07 \pm 0.01^{*} \ddagger$ & $0.12 \pm 0.02$ & $0.04 \pm 0.01^{*}$ \\
PGE-2 & & & & & \\
Control & $0.11 \pm 0.01$ & $0.16 \pm 0.02$ & $0.22 \pm 0.03^{\dagger}$ & $0.08 \pm 0.01$ & $0.04 \pm 0.01 \S$ \\
Actin. D & - & $0.12 \pm 0.01^{*}$ & $0.13 \pm 0.01^{*}$ & $0.08 \pm 0.01$ & $0.02 \pm 0.01$ \\
Cyclohex. & - & $0.11 \pm 0.01^{*}$ & $0.09 \pm 0.01^{*} \ddagger$ & $0.10 \pm 0.01$ & $0.05 \pm 0.01$ \\
Puromy. & - & $0.11 \pm 0.01^{*}$ & $0.11 \pm 0.01^{*}$ & $0.09 \pm 0.01$ & $0.04 \pm 0.01$ \\
6-KF & & & & & \\
Control & $0.16 \pm 0.01$ & $0.40 \pm 0.04 \dagger$ & $0.37 \pm 0.04 \dagger$ & $0.81 \pm 0.06$ & $0.32 \pm 0.03 \S$ \\
Actin. D & - & $0.30 \pm 0.02^{*} \dagger$ & $0.28 \pm 0.03^{*} \dagger$ & $0.80 \pm 0.05$ & $0.21 \pm 0.02^{*}$ \\
Cyclohex. & - & $0.23 \pm 0.02^{*} \dagger$ & $0.19 \pm 0.02^{*}$ & $0.76 \pm 0.06$ & $0.18 \pm 0.02^{*}$ \\
Puromy. & - & $0.24 \pm 0.02^{*} \dagger$ & $0.19 \pm 0.02^{*}$ & $0.84 \pm 0.07$ & $0.20 \pm 0.02^{*}$ \\
\hline
\end{tabular}

Day 15

\begin{tabular}{|c|c|c|c|c|c|}
\hline \multicolumn{6}{|l|}{ PGF- $2 \alpha$} \\
\hline Control & $0.25 \pm 0.03$ & $0.81 \pm 0.12 \dagger$ & $0.98 \pm 0.18 \dagger$ & $3 \cdot 10 \pm 0.37$ & $2 \cdot 78 \pm 0 \cdot 70$ \\
\hline Actin. D & - & $0.38 \pm 0.04 * \dagger$ & $0.29 \pm 0.06^{*}$ & $1.85 \pm 0.21^{*}$ & $0 \cdot 76 \pm 0 \cdot 16^{*}$ \\
\hline Cyclohex. & - & $0.19 \pm 0.02^{*}$ & $0 \cdot 16 \pm 0 \cdot 02^{*} t$ & $1.21 \pm 0.13^{*}$ & $0.21 \pm 0.03^{*}$ \\
\hline Puromy. & - & $0.20 \pm 0.04^{*}$ & $0.14 \pm 0.03^{*}$ & $1 \cdot 32 \pm 0.15^{*}$ & $0.17 \pm 0.02 *$ \\
\hline \multicolumn{6}{|l|}{ PGE-2 } \\
\hline Control & $0.16 \pm 0.01$ & $0.42 \pm 0.07 \dagger$ & $0.56 \pm 0.12 \uparrow$ & $0.17 \pm 0.01$ & $0.15 \pm 0.03$ \\
\hline Actin. D & 二 & $0.20 \pm 0.02 *$ & $0.17 \pm 0.13^{*}$ & $0.15 \pm 0.01$ & $0.07 \pm 0.01^{*}$ \\
\hline Cyclohex. & - & $0.11 \pm 0.01^{*} \ddagger$ & $0.13 \pm 0.01 * t$ & $0.16 \pm 0.01$ & $0.07 \pm 0.01^{*}$ \\
\hline Puromy. & - & $0.14 \pm 0.01^{*}$ & $0.10 \pm 0.01 *$ & $0.12 \pm 0.01^{*}$ & $0.04 \pm 0.01^{*}$ \\
\hline \multicolumn{6}{|l|}{ 6-KF } \\
\hline Control & $0.27 \pm 0.03$ & $0.79 \pm 0.16 \dagger$ & $0.60 \pm 0.10 \dagger$ & $0.78 \pm 0.08$ & $0.34 \pm 0.06 \S$ \\
\hline Actin. D & 二 & $0.47 \pm 0.04 \dagger$ & $0.41 \pm 0.05^{* \dagger}$ & $0.69 \pm 0.04$ & $0.22 \pm 0.04$ \\
\hline Cyclohex. & - & $0.33 \pm 0.04^{*}$ & $0.34 \pm 0.03^{*}$ & $0.54 \pm 0.06^{*}$ & $0.17 \pm 0.03^{*}$ \\
\hline Puromy. & - & $0.34 \pm 0.03^{*}$ & $0.28 \pm 0.03^{*}$ & $0.53 \pm 0.07^{*}$ & $0.17 \pm 0.02^{*}$ \\
\hline
\end{tabular}

$\dagger$ Significantly $(P<0.05)$ higher than corresponding control value for the same $\mathrm{PG}$ at $0 \mathrm{~h}$.

*Significantly $(P<0.05)$ lower than corresponding control value for the same PG at the same time.

$\ddagger$ Significantly $(P<0.05)$ lower than corresponding control value for the same PG at $0 \mathrm{~h}$.

$\S$ Significantly $(P<0.05)$ lower than the control output of the same PG at $6 \mathrm{~h}$.

uterus and 6-keto-PGF-1 $\alpha$ output from the Day-7 and Day-15 uterus. Cycloheximide significantly $(P<0.05)$ increased PGF-2 $\alpha$ output from the Day-7 uterus, and PGE-2 and 6-keto-PGF-1 $\alpha$ outputs from the Day-7 and Day-15 uterus. Puromycin significantly $(P<0.05)$ increased 6-ketoPGF-1 $\alpha$ output from the Day-7 and Day-15 uterus. None of the 3 protein synthesis inhibitors affected the amounts of PGF-2 $\alpha$, PGE-2 and 6-keto-PGF-1 $\alpha$, synthesized after the period of superfusion by homogenates of the endometrium and myometrium (Table 4). 
Table 2. Effects of actinomycin D (Actin. D), cycloheximide (Cyclohex.) and puromycin (Puromy.) on the mean ( \pm s.e.m., $n=5$ ) outputs of prostaglandin (PG) F-2 $\alpha$, PGE-2, 6-keto-PGF-1 $\alpha(6-\mathrm{KF}$ ) from the Day-7 guinea-pig uterus superfused in vitro when present at a concentration of $50 \mu \mathrm{g} / \mathrm{ml}$ during the collection of samples 4 and 5

\begin{tabular}{|c|c|c|c|c|c|c|c|c|}
\hline \multirow[b]{2}{*}{ Treatment } & \multicolumn{8}{|c|}{ PG output (pg/min/100 mg tissue) } \\
\hline & $\underset{1}{\text { Sample }}$ & $\underset{2}{\text { Sample }}$ & $\underset{3}{\text { Sample }}$ & $\begin{array}{c}\text { Sample } \\
4\end{array}$ & $\underset{5}{\text { Sample }}$ & $\begin{array}{c}\text { Sample } \\
6\end{array}$ & $\underset{7}{\text { Sample }}$ & $\begin{array}{c}\text { Sample } \\
8\end{array}$ \\
\hline \multicolumn{9}{|l|}{ PGF- $2 \alpha$} \\
\hline $\begin{array}{l}\text { Control } \\
\text { Actin. D }\end{array}$ & $\begin{array}{ll}6 \pm & 1 \\
8 \pm & 2\end{array}$ & $\begin{array}{l}6 \pm 1 \\
7 \pm 1\end{array}$ & $\begin{array}{l}6 \pm 1 \\
6 \pm 1\end{array}$ & $\begin{array}{c}5 \pm 1 \\
10 \pm 2^{*}\end{array}$ & $\begin{array}{l}7 \pm 2 \\
9 \pm 1\end{array}$ & $\begin{array}{l}6 \pm 1 \\
7 \pm 1\end{array}$ & $\begin{array}{l}6 \pm 1 \\
5 \pm 1\end{array}$ & $\begin{array}{l}5 \pm 1 \\
6 \pm 2\end{array}$ \\
\hline $\begin{array}{l}\text { Control } \\
\text { Cyclohex. }\end{array}$ & $\begin{array}{r}9 \pm 1 \\
11 \pm 1\end{array}$ & $\begin{array}{r}8 \pm 1 \\
10 \pm 1\end{array}$ & $\begin{array}{l}9 \pm 1 \\
9 \pm 1\end{array}$ & $\begin{aligned} 8 \pm & 1 \\
15 \pm & 1^{*}\end{aligned}$ & $\begin{array}{c}9 \pm 1 \\
13 \pm 1 *\end{array}$ & $\begin{array}{l}8 \pm 1 \\
9 \pm 1\end{array}$ & $\begin{array}{l}9 \pm 1 \\
8 \pm 1\end{array}$ & $\begin{array}{l}8 \pm 1 \\
8 \pm 1\end{array}$ \\
\hline $\begin{array}{l}\text { Control } \\
\text { Puromy. }\end{array}$ & $\begin{array}{l}8 \pm 2 \\
7 \pm 1\end{array}$ & $\begin{array}{l}6 \pm 1 \\
6 \pm 1\end{array}$ & $\begin{array}{l}8 \pm 1 \\
6 \pm 1\end{array}$ & $\begin{array}{l}7 \pm 2 \\
6 \pm 1\end{array}$ & $\begin{array}{l}7 \pm 1 \\
5 \pm 1\end{array}$ & $\begin{array}{l}8 \pm 2 \\
7 \pm 1\end{array}$ & $\begin{array}{l}8 \pm 2 \\
7 \pm 1\end{array}$ & $\begin{array}{l}8 \pm 2 \\
6 \pm 1\end{array}$ \\
\hline \multicolumn{9}{|l|}{ PGE-2 } \\
\hline $\begin{array}{l}\text { Control } \\
\text { Actin. D }\end{array}$ & $\begin{array}{l}32 \pm 6 \\
40 \pm 11\end{array}$ & $\begin{array}{l}26 \pm 7 \\
30 \pm 4\end{array}$ & $\begin{array}{l}27 \pm 8 \\
35 \pm 6\end{array}$ & $\begin{array}{l}23 \pm 3 \\
33 \pm 5\end{array}$ & $\begin{array}{l}27 \pm 4 \\
33 \pm 5\end{array}$ & $\begin{array}{l}22 \pm 2 \\
22 \pm 3\end{array}$ & $\begin{array}{l}20 \pm 2 \\
18 \pm 1\end{array}$ & $\begin{array}{l}23 \pm 4 \\
22 \pm 3\end{array}$ \\
\hline $\begin{array}{l}\text { Control } \\
\text { Cyclohex. }\end{array}$ & $\begin{array}{l}42 \pm 25 \\
50 \pm 24\end{array}$ & $\begin{array}{l}22 \pm 6 \\
42 \pm 22\end{array}$ & $\begin{array}{l}16 \pm 4 \\
18 \pm 5\end{array}$ & $\begin{array}{l}13 \pm 3 \\
95 \pm 8^{*}\end{array}$ & $\begin{array}{c}10 \pm 3 \\
114 \pm 16^{*}\end{array}$ & $\begin{array}{l}13 \pm 4 \\
35 \pm 8^{*}\end{array}$ & $\begin{array}{l}18 \pm 3 \\
25 \pm 10\end{array}$ & $\begin{array}{l}13 \pm 6 \\
19 \pm 5\end{array}$ \\
\hline $\begin{array}{l}\text { Control } \\
\text { Puromy. }\end{array}$ & $\begin{array}{l}18 \pm 3 \\
14 \pm \quad 1\end{array}$ & $\begin{array}{l}15 \pm 4 \\
16 \pm 3\end{array}$ & $\begin{array}{l}13 \pm 1 \\
16 \pm 5\end{array}$ & $\begin{array}{l}12 \pm 2 \\
14 \pm 4\end{array}$ & $\begin{array}{l}11 \pm 4 \\
17 \pm 4\end{array}$ & $\begin{array}{l}13 \pm 3 \\
13 \pm 3\end{array}$ & $\begin{array}{l}13 \pm 4 \\
19 \pm 4\end{array}$ & $\begin{array}{l}12 \pm 3 \\
15 \pm 4\end{array}$ \\
\hline $\begin{array}{l}\text { 6-KF } \\
\text { Control } \\
\text { Actin. D }\end{array}$ & $\begin{array}{l}21 \pm 3 \\
20 \pm 4\end{array}$ & $\begin{array}{l}15 \pm 1 \\
22 \pm 4\end{array}$ & $\begin{array}{l}15 \pm 2 \\
17 \pm 2\end{array}$ & $\begin{array}{l}14 \pm 2 \\
37 \pm 8^{*}\end{array}$ & $\begin{array}{l}20 \pm 2 \\
40 \pm 2^{*}\end{array}$ & $\begin{array}{l}17 \pm 4 \\
24 \pm 3\end{array}$ & $\begin{array}{l}16 \pm 4 \\
16 \pm 4\end{array}$ & $\begin{array}{l}12 \pm 1 \\
13 \pm 3\end{array}$ \\
\hline $\begin{array}{l}\text { Control } \\
\text { Cyclohex. }\end{array}$ & $\begin{array}{l}17 \pm 3 \\
25 \pm 5\end{array}$ & $\begin{array}{l}15 \pm 1 \\
22 \pm 4\end{array}$ & $\begin{array}{l}15 \pm 2 \\
17 \pm 2\end{array}$ & $\begin{array}{l}13 \pm 2 \\
34 \pm 13^{*}\end{array}$ & $\begin{array}{l}13 \pm 3 \\
27 \pm 2^{*}\end{array}$ & $\begin{array}{l}14 \pm 3 \\
13 \pm 2\end{array}$ & $\begin{array}{l}14 \pm 2 \\
11 \pm 2\end{array}$ & $\begin{array}{l}15 \pm 2 \\
12 \pm 3\end{array}$ \\
\hline $\begin{array}{l}\text { Control } \\
\text { Puromy. }\end{array}$ & $\begin{array}{l}17 \pm 2 \\
16 \pm 3\end{array}$ & $\begin{array}{ll}16 \pm & 2 \\
18 \pm & 4\end{array}$ & $\begin{array}{l}16 \pm 2 \\
18 \pm 4\end{array}$ & $\begin{array}{l}15 \pm 3 \\
26 \pm 6^{*}\end{array}$ & $\begin{array}{l}15 \pm 3 \\
22 \pm 4\end{array}$ & $\begin{array}{l}17 \pm 2 \\
16 \pm 2\end{array}$ & $\begin{array}{l}14 \pm 2 \\
16 \pm 2\end{array}$ & $\begin{array}{l}12 \pm 1 \\
14 \pm 2\end{array}$ \\
\hline
\end{tabular}

*Significantly $(P<0 \cdot 05)$ higher than corresponding control value for same PG for the same sample number.

Experiment 4: protein synthesis in cultured endometrium and the effects of protein synthesis inhibitors

Methods. In Exp. 4A, 6 dishes of endometrium (30-60 mg/dish) were prepared from each uterus obtained from five Day- 7 and five Day- 15 guinea-pigs. Each dish contained $10 \mu \mathrm{Ci}\left[{ }^{3} \mathrm{H}\right]$ leucine. The 6 dishes were placed in a Kilner jar and the endometrium was incubated for periods up to $24 \mathrm{~h}$.

Immediately after the jar was placed in the incubator, $30-60 \mathrm{mg}$ of the remaining endometrium from each animal were placed in another Petri dish containing $10 \mu \mathrm{Ci}\left[{ }^{3} \mathrm{H}\right]$ leucine. The endometrium in the dish was rinsed with the $\left[{ }^{3} \mathrm{H}\right]$ leucine-containing medium and was left for $2 \mathrm{~min}$ at room temperature. The endometrium was removed and weighed. The endometrium and culture medium were then subjected to the procedures for measuring the amounts of $\left[{ }^{3} \mathrm{H}\right]$ leucine incorporated into cellular and secreted proteins, respectively, in order to measure the amounts of $\left[{ }^{3} \mathrm{H}\right]$ leucine which were bound non-specifically.

After $1,2,4,8,12$ and $24 \mathrm{~h}$ of culture, one dish was removed from the Kilner jar and the amounts of $\left[{ }^{3} \mathrm{H}\right]$ leucine incorporated into cellular and secreted proteins by the endometrium were measured. For each set of dishes, the amounts of $\left[{ }^{3} \mathrm{H}\right]$ leucine bound non-specifically were subtracted from the amounts of $\left[{ }^{3} \mathrm{H}\right]$ leucine incorporated into cellular and secreted proteins, respectively. The lines of best fit for $\left[{ }^{3} \mathrm{H}\right]$ leucine incorporation into cellular and secreted proteins by Day- 7 and Day-15 endometrium were calculated by linear regression analysis.

In Exp. 4B, 4 dishes of endometrium (30-60 mg/dish) were prepared from each uterus obtained from five Day-7 and five Day- $\mathbf{6}$ guinea-pigs. For each group of 4 dishes, 1 dish was untreated (control), and actinomycin D $(50 \mu \mathrm{g} / \mathrm{ml})$, cyclocheximide $(10 \mu \mathrm{g} / \mathrm{ml})$ or puromycin $(50 \mu \mathrm{g} / \mathrm{ml})$ 
Table 3. Effects of actinomycin D (Actin. D), cycloheximide (Cyclohex.) and puromycin (Puromy.) on the mean ( \pm s.e.m., $n=5$ ) outputs of prostaglandin (PG) F-2 $\alpha$, PGE-2, 6-keto-PGF-1 $\alpha$ (6-KF) from the Day-15 guinea-pig uterus superfused in vitro when present at a concentration of $50 \mu \mathrm{g} / \mathrm{ml}$ during the collection of samples 4 and 5

\begin{tabular}{|c|c|c|c|c|c|c|c|c|}
\hline \multirow[b]{2}{*}{ Treatment } & \multicolumn{8}{|c|}{ PG output (pg/min $/ 100 \mathrm{mg}$ tissue) } \\
\hline & Sample & $\begin{array}{l}\text { Sampie } \\
2\end{array}$ & $\begin{array}{c}\text { Sample } \\
3\end{array}$ & $\begin{array}{l}\text { Sampie } \\
4\end{array}$ & $\begin{array}{l}\text { Sample } \\
5\end{array}$ & $\underset{6}{\text { Sample }}$ & $\underset{7}{\text { Sample }}$ & $\begin{array}{c}\text { Sample } \\
8\end{array}$ \\
\hline \multicolumn{9}{|l|}{ PGF- $2 \alpha$} \\
\hline $\begin{array}{l}\text { Control } \\
\text { Actin. D }\end{array}$ & $\begin{array}{l}149 \pm 20 \\
136 \pm 21\end{array}$ & $\begin{array}{l}169 \pm 24 \\
138 \pm 21\end{array}$ & $\begin{array}{l}142 \pm 18 \\
126 \pm 24\end{array}$ & $\begin{array}{l}165 \pm 48 \\
126 \pm 14\end{array}$ & $\begin{array}{l}127 \pm 29 \\
109 \pm 15\end{array}$ & $\begin{array}{r}128 \pm 33 \\
68 \pm 19\end{array}$ & $\begin{array}{r}134 \pm 35 \\
69 \pm 15\end{array}$ & $\begin{array}{r}120 \pm 24 \\
71 \pm 10\end{array}$ \\
\hline $\begin{array}{l}\text { Control } \\
\text { Cyclohex. }\end{array}$ & $\begin{array}{l}240 \pm 31 \\
272 \pm 43\end{array}$ & $\begin{array}{l}235 \pm 47 \\
239 \pm 24\end{array}$ & $\begin{array}{l}213 \pm 46 \\
212 \pm 17\end{array}$ & $\begin{array}{l}208 \pm 45 \\
247 \pm 24\end{array}$ & $\begin{array}{l}177 \pm 37 \\
218 \pm 27\end{array}$ & $\begin{array}{l}178 \pm 41 \\
166 \pm 34\end{array}$ & $\begin{array}{l}191 \pm 46 \\
132 \pm 24\end{array}$ & $\begin{array}{l}168 \pm 46 \\
169 \pm 24\end{array}$ \\
\hline $\begin{array}{l}\text { Control } \\
\text { Puromy. }\end{array}$ & $\begin{array}{l}255 \pm 83 \\
260 \pm 65\end{array}$ & $\begin{array}{l}236 \pm 61 \\
225 \pm 62\end{array}$ & $\begin{array}{l}225 \pm 72 \\
204 \pm 56\end{array}$ & $\begin{array}{l}214 \pm 64 \\
227 \pm 54\end{array}$ & $\begin{array}{l}171 \pm 43 \\
205 \pm 54\end{array}$ & $\begin{array}{l}157 \pm 40 \\
149 \pm 42\end{array}$ & $\begin{array}{l}152 \pm 38 \\
137 \pm 27\end{array}$ & $\begin{array}{l}141 \pm 32 \\
128 \pm 23\end{array}$ \\
\hline \multicolumn{9}{|l|}{ PGE-2 } \\
\hline $\begin{array}{l}\text { Control } \\
\text { Actin. D }\end{array}$ & $\begin{array}{l}30 \pm 3 \\
49 \pm 11\end{array}$ & $\begin{array}{ll}30 \pm & 3 \\
43 \pm & 7\end{array}$ & $\begin{array}{l}27 \pm 3 \\
36 \pm 9\end{array}$ & $\begin{array}{l}32 \pm 4 \\
48 \pm 10\end{array}$ & $\begin{array}{ll}25 \pm & 3 \\
55 \pm & 9^{*}\end{array}$ & $\begin{array}{l}25 \pm I \\
30 \pm 5\end{array}$ & $\begin{array}{l}21 \pm 1 \\
25 \pm 2\end{array}$ & $\begin{array}{l}24 \pm 2 \\
27 \pm 2\end{array}$ \\
\hline $\begin{array}{l}\text { Control } \\
\text { Cyclohex. }\end{array}$ & $\begin{array}{l}22 \pm 3 \\
28 \pm 6\end{array}$ & $\begin{array}{l}24 \pm 6 \\
28 \pm 5\end{array}$ & $\begin{array}{l}20 \pm 5 \\
26 \pm 4\end{array}$ & $\begin{array}{c}18 \pm 2 \\
151 \pm 20^{*}\end{array}$ & $\begin{array}{c}17 \pm 3 \\
141 \pm 19^{*}\end{array}$ & $\begin{array}{l}18 \pm 3 \\
54 \pm 12\end{array}$ & $\begin{array}{l}20 \pm 4 \\
22 \pm 4\end{array}$ & $\begin{array}{l}18 \pm 4 \\
26 \pm 7\end{array}$ \\
\hline $\begin{array}{l}\text { Control } \\
\text { Puromy. }\end{array}$ & $\begin{array}{l}22 \pm 6 \\
28 \pm 7\end{array}$ & $\begin{array}{l}22 \pm 6 \\
25 \pm 7\end{array}$ & $\begin{array}{l}16 \pm 4 \\
27 \pm 8\end{array}$ & $\begin{array}{l}22 \pm 6 \\
24 \pm 3\end{array}$ & $\begin{array}{l}18 \pm 5 \\
25 \pm 5\end{array}$ & $\begin{array}{l}22 \pm 7 \\
23 \pm 4\end{array}$ & $\begin{array}{l}17 \pm 6 \\
21 \pm 6\end{array}$ & $\begin{array}{ll}14 \pm & 4 \\
23 \pm & 6\end{array}$ \\
\hline \multicolumn{9}{|l|}{$6-\mathrm{KF}$} \\
\hline $\begin{array}{l}\text { Control } \\
\text { Actin. D }\end{array}$ & $\begin{array}{l}33 \pm 5 \\
31 \pm 7\end{array}$ & $\begin{array}{ll}31 \pm & 3 \\
31 \pm & 5\end{array}$ & $\begin{array}{l}38 \pm 7 \\
30 \pm 4\end{array}$ & $\begin{array}{l}28 \pm 4 \\
68 \pm 4^{*}\end{array}$ & $\begin{array}{l}27 \pm 6 \\
67 \pm 6^{*}\end{array}$ & $\begin{array}{l}24 \pm 2 \\
39 \pm 6\end{array}$ & $\begin{array}{l}22 \pm 2 \\
26 \pm 4\end{array}$ & $\begin{array}{l}23 \pm 3 \\
23 \pm 2\end{array}$ \\
\hline $\begin{array}{l}\text { Control } \\
\text { Cyclohex. }\end{array}$ & $\begin{array}{l}30 \pm 4 \\
36 \pm 5\end{array}$ & $\begin{array}{l}29 \pm 4 \\
43 \pm 6\end{array}$ & $\begin{array}{l}35 \pm 3 \\
36 \pm 5\end{array}$ & $\begin{array}{l}29 \pm 3^{3} \\
62 \pm 11^{*}\end{array}$ & $\begin{array}{ll}30 \pm & 3 \\
43 \pm & 2 *\end{array}$ & $\begin{array}{l}31 \pm 4 \\
31 \pm 4\end{array}$ & $\begin{array}{l}26 \pm 4 \\
26 \pm 4\end{array}$ & $\begin{array}{l}29 \pm 6 \\
29 \pm 6\end{array}$ \\
\hline $\begin{array}{l}\text { Control } \\
\text { Puromy. }\end{array}$ & $\begin{array}{l}36 \pm 3 \\
36 \pm 3\end{array}$ & $\begin{array}{l}36 \pm 2 \\
33 \pm 3\end{array}$ & $\begin{array}{l}27 \pm 2 \\
39 \pm 3\end{array}$ & $\begin{array}{l}32 \pm 2 \\
50 \pm 4^{*}\end{array}$ & $\begin{array}{l}31 \pm 2 \\
44 \pm 3^{*}\end{array}$ & $\begin{array}{l}26 \pm 2 \\
31 \pm 6\end{array}$ & $\begin{array}{l}26 \pm 2 \\
32 \pm 5\end{array}$ & $\begin{array}{l}24 \pm 2 \\
27 \pm 2\end{array}$ \\
\hline
\end{tabular}

*Significantly $(P<0.05)$ higher than corresponding control output for same PG for the same sample number.

was added to the other 3 dishes. Each dish also contained $10 \mu \mathrm{Ci}\left[{ }^{3} \mathrm{H}\right]$ leucine. The 4 dishes were placed in a Kilner jar and the endometrium was cultured for $24 \mathrm{~h}$. The amounts of $\left[{ }^{3} \mathrm{H}\right]$ leucine incorporated into cellular and secreted proteins by the endometrium were measured. After placing the dishes in the Kilner jar, another $30-60 \mathrm{mg}$ endometrium were rinsed with $\left[{ }^{3} \mathrm{H}\right]$ leucine-containing medium in order to measure the non-specific binding of $\left[{ }^{3} \mathrm{H}\right]$ leucine. The amounts of $\left[{ }^{3} \mathrm{H}\right] \mathrm{leu}-$ cine bound non-specifically were subtracted from the amounts incorporated into the two types of protein after $24 \mathrm{~h}$ of culture.

Results. Linear increases occurred in the amounts of $\left[{ }^{3} \mathrm{H}\right]$ leucine which were incorporated into cellular and secreted proteins by Day- 7 and Day-15 endometrium over a $24 \mathrm{~h}$ period of culture (Fig. 4). There were no significant differences in the amounts of $\left[{ }^{3} \mathrm{H}\right]$ leucine incorporated into cellular proteins between Day-7 and Day-15 endometrium. However, significantly $(P<0.05)$ greater amounts of $\left[{ }^{3} \mathrm{H}\right]$ leucine were incorporated into secreted proteins by Day- 15 endometrium than by Day-7 endometrium (Fig. 4). Actinomycin D $(50 \mu \mathrm{g} / \mathrm{ml})$, cycloheximide $(10 \mu \mathrm{g} / \mathrm{ml})$ and puromycin $(50 \mu \mathrm{g} / \mathrm{ml})$ significantly $(P<0.05)$ reduced the amounts of $\left[{ }^{3} \mathrm{H}\right]$ leucine incorporated into cellular and secreted proteins by Day-7 and Day-15 endometrium during a 24-h period of culture (Fig. 5).

\section{Experiment 5: effects of actinomycin D treatment in vivo}

Methods. Ten Day-10 guinea-pigs were anaesthetized by the intraperitoneal injection of Hypnorm (i.e. fentanyl citrate, $0.47 \mathrm{mg} / \mathrm{kg}$, and fluanisone, $15 \mathrm{mg} / \mathrm{kg}$ ) and Hypnovel (i.e., midazolam, 
Table 4. Effects of actinomycin D (Actin. D), cycloheximide (Cyclohex.) and puromycin (Puromy.) on the mean ( \pm s.e.m., $n=5$ ) amounts of prostaglandin (PG) F-2 $\alpha$, PGE-2 and 6-keto-PGF-1 $\alpha(6-K F)$ produced by homogenates of endometrium and myometrium following superfusion of the Day-7 and Day-15 guinea-pig uterus in vitro when present at a concentration of $50 \mu \mathrm{g} / \mathrm{ml}$ for $20 \mathrm{~min}$

\begin{tabular}{|c|c|c|c|c|}
\hline \multirow[b]{3}{*}{ Treatment } & \multicolumn{4}{|c|}{ PG production (ng/100 mg tissue) } \\
\hline & \multicolumn{2}{|c|}{ Day 7} & \multicolumn{2}{|c|}{ Day 15} \\
\hline & Endometrium & Myometrium & Endometrium & Myometrium \\
\hline \multicolumn{5}{|l|}{ PGF- $2 \alpha$} \\
\hline $\begin{array}{l}\text { Control } \\
\text { Actin. D }\end{array}$ & $\begin{array}{l}7.64 \pm 0.72 \\
7.54 \pm 1 \cdot 16\end{array}$ & $\begin{array}{l}8.14 \pm 0.69 \\
8.60 \pm 0.96\end{array}$ & $\begin{array}{l}25.14 \pm 4.97 \\
17.42 \pm 3.72\end{array}$ & $\begin{array}{l}8.33 \pm 0.98 \\
7.40 \pm 0.86\end{array}$ \\
\hline $\begin{array}{l}\text { Control } \\
\text { Cyclohex. }\end{array}$ & $\begin{array}{l}7 \cdot 93 \pm 0.96 \\
5.58 \pm 0.45\end{array}$ & $\begin{array}{l}7.58 \pm 0.65 \\
8.73 \pm 0.28\end{array}$ & $\begin{array}{l}39 \cdot 16 \pm 5 \cdot 52 \\
34 \cdot 60 \pm 3 \cdot 56\end{array}$ & $\begin{array}{l}16.04 \pm 1.73 \\
13.63 \pm 1.11\end{array}$ \\
\hline $\begin{array}{l}\text { Control } \\
\text { Puromy. }\end{array}$ & $\begin{array}{l}9 \cdot 55 \pm 1 \cdot 76 \\
9 \cdot 30 \pm 1 \cdot 68\end{array}$ & $\begin{array}{ll}7.54 \pm 1.28 \\
8.52 \pm 1.68\end{array}$ & $\begin{array}{l}27 \cdot 29 \pm 5 \cdot 61 \\
20 \cdot 48 \pm 5 \cdot 31\end{array}$ & $\begin{array}{l}10.92 \pm 1.22 \\
13.03 \pm 2.00\end{array}$ \\
\hline $\begin{array}{l}\text { PGE-2 } \\
\text { Control } \\
\text { Actin. D }\end{array}$ & $\begin{array}{l}6.63 \pm 0.81 \\
5.99 \pm 0.91\end{array}$ & $\begin{array}{l}9 \cdot 13 \pm 0.60 \\
9 \cdot 20 \pm 0 \cdot 75\end{array}$ & $\begin{array}{l}8 \cdot 76 \pm 1 \cdot 14 \\
6 \cdot 08 \pm 0.84\end{array}$ & $\begin{array}{l}7.81 \pm 0.38 \\
7.87 \pm 0.46\end{array}$ \\
\hline $\begin{array}{l}\text { Control } \\
\text { Cyclohex. }\end{array}$ & $\begin{array}{l}6 \cdot 13 \pm 1.22 \\
4.24 \pm 0.85\end{array}$ & $\begin{array}{l}8.14 \pm 0.77 \\
7.74 \pm 0.85\end{array}$ & $\begin{array}{l}7.47 \pm 0.93 \\
5.38 \pm 0.96\end{array}$ & $\begin{array}{l}7.25 \pm 1 \cdot 17 \\
7 \cdot 21 \pm 0 \cdot 80\end{array}$ \\
\hline $\begin{array}{l}\text { Control } \\
\text { Puromy. }\end{array}$ & $\begin{array}{l}6.08 \pm 0.85 \\
5.63 \pm 0.51\end{array}$ & $\begin{array}{l}6.82 \pm 1.04 \\
8.02 \pm 0.76\end{array}$ & $\begin{array}{l}7.47 \pm 0.93 \\
5.38 \pm 0.96\end{array}$ & $\begin{array}{l}7 \cdot 25 \pm 1 \cdot 17 \\
7 \cdot 21 \pm 0.80\end{array}$ \\
\hline \multicolumn{5}{|l|}{$6-\mathrm{KF}$} \\
\hline $\begin{array}{l}\text { Control } \\
\text { Actin. D }\end{array}$ & $\begin{array}{l}24 \cdot 00 \pm 3 \cdot 24 \\
20 \cdot 25 \pm 3 \cdot 88\end{array}$ & $\begin{array}{l}68.03 \pm 7.49 \\
69.34 \pm 8.53\end{array}$ & $\begin{array}{l}35.61 \pm 5.98 \\
26.17 \pm 3.66\end{array}$ & $\begin{array}{l}72.79 \pm 9.27 \\
70 \cdot 28 \pm 4.96\end{array}$ \\
\hline $\begin{array}{l}\text { Control } \\
\text { Cyclohex. }\end{array}$ & $\begin{array}{l}18.99 \pm 2.36 \\
14.60 \pm 1.96\end{array}$ & $\begin{array}{l}58.02 \pm 5.23 \\
66.87 \pm 6.74\end{array}$ & $\begin{array}{l}38.79 \pm 4.57 \\
41.49 \pm 5.54\end{array}$ & $\begin{array}{r}96.64 \pm 2.31 \\
91.59 \pm 12.24\end{array}$ \\
\hline $\begin{array}{l}\text { Control } \\
\text { Puromy. }\end{array}$ & $\begin{array}{l}23 \cdot 15 \pm 6 \cdot 15 \\
17 \cdot 56 \pm 4 \cdot 04\end{array}$ & $\begin{array}{l}58.05 \pm 12.48 \\
49.95 \pm 8.28\end{array}$ & $\begin{array}{l}34.08 \pm 3.71 \\
27.06 \pm 4.40\end{array}$ & $\begin{array}{r}77.94 \pm 11.83 \\
89.73 \pm 9.94\end{array}$ \\
\hline
\end{tabular}

$3 \mathrm{mg} / \mathrm{kg}$ ). An abdominal incision was made and the uterus was exposed. Each uterine horn received an injection into the lumen of $0.5 \mathrm{ml}$ sterile saline $(9 \mathrm{~g} / 1,5$ animals $)$ or $0.5 \mathrm{ml}$ sterile saline containing $20 \mu \mathrm{g}$ actinomycin D (5 animals). Each guinea-pig was killed on Day 15, and the uterus was removed and separated into endometrium and myometrium. Two Petri dishes containing $12-20 \mathrm{mg}$ endometrium, two dishes containing $15-25 \mathrm{mg}$ myometrium, and one dish containing $10 \mu \mathrm{Ci}$ $\left[{ }^{3} \mathrm{H}\right]$ leucine and $30-60 \mathrm{mg}$ of endometrium were prepared from each uterus. These 5 dishes were placed in a Kilner jar, and the tissues were cultured for $24 \mathrm{~h}$. Immediately after the dishes were placed in the incubator, 30-60 mg endometrium from each uterus were rinsed in medium containing $10 \mu \mathrm{Ci}\left[{ }^{3} \mathrm{H}\right]$ leucine in order to measure the non-specific binding of $\left[{ }^{3} \mathrm{H}\right]$ leucine, as described in Exp. 4.

After $24 \mathrm{~h}$, the dishes were removed from the incubator and the samples of culture medium not containing $\left[{ }^{3} \mathrm{H}\right]$ leucine were stored at $-20^{\circ} \mathrm{C}$ before being assayed for PGF-2 $\alpha$, PGE-2 and 6-ketoPGF-1 $\alpha$. The tissue and culture medium in the 5 th dish were used to measure the amounts of $\left[{ }^{3} \mathrm{H}\right]$ leucine incorporated into cellular and secreted proteins by the endometrium.

Results. The intrauterine administration of actinomycin D on Day 10 significantly $(P<0.05)$ reduced the mean ( \pm s.e.m., $n=5$ ) amounts of $\left[{ }^{3} \mathrm{H}\right]$ leucine incorporated into endometrial proteins during tissue culture for $24 \mathrm{~h}$ from $24842 \pm 5932$ to $7327 \pm 2579$ c.p.m./mg tissue $/ 10^{6}$ standard 


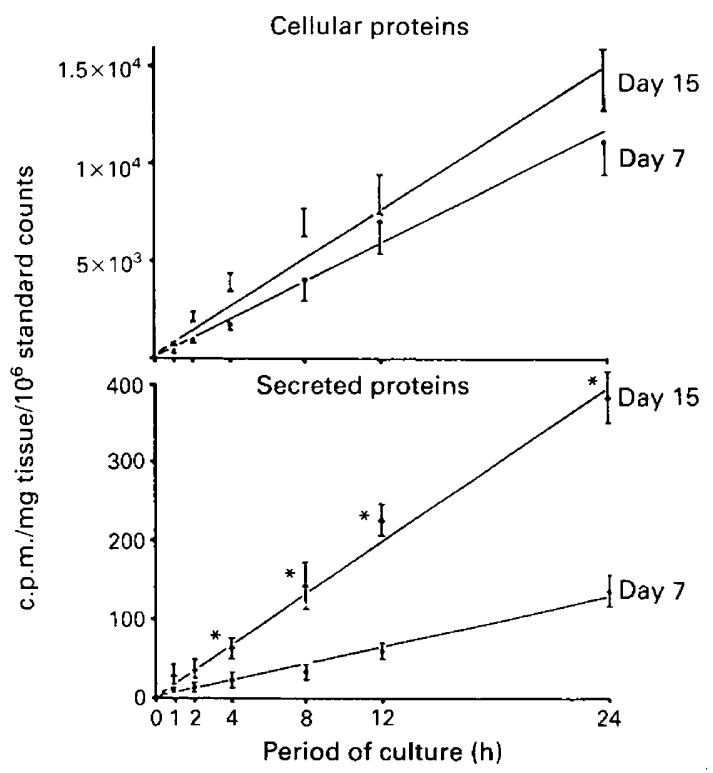

Fig. 4. Mean ( \pm s.e.m., $n=5$ ) amounts of $\left[{ }^{3} \mathrm{H}\right]$ leucine incorporated into cellular and secreted proteins by Day-7 and Day-15 guinea-pig endometrium over a 24-h period of culture $(r>0.98$ for all 4 lines). *Significantly $(P<0.05)$ higher than the amount of protein secreted by Day-7 endometrium at the same time.

(i) Day 7

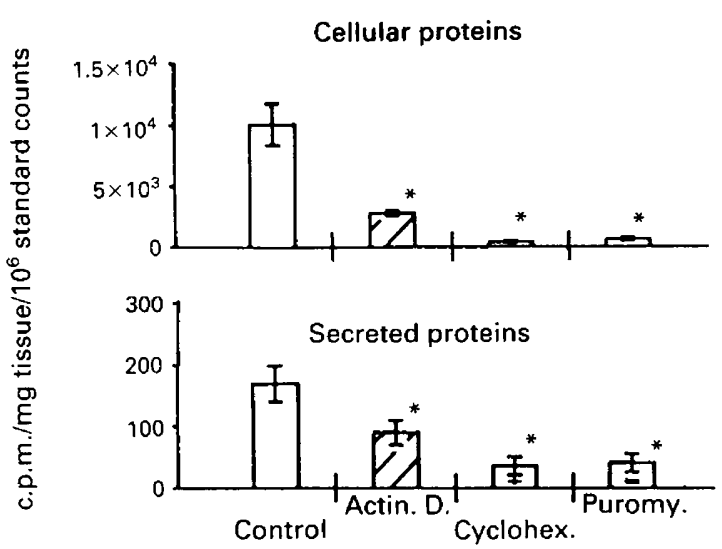

(ii) Day 15

Cellular proteins

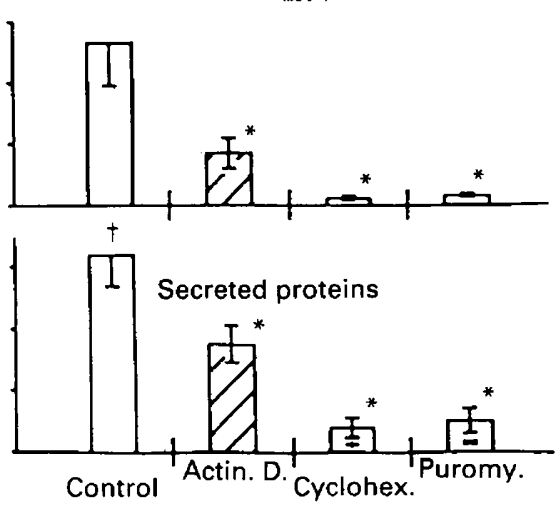

Fig. 5. Effects of actinomycin D (Actin. D, $50 \mu \mathrm{g} / \mathrm{ml}$ ), cycloheximide (Cyclohex., $10 \mu \mathrm{g} / \mathrm{ml}$ ) and puromycin (Puromy., $50 \mu \mathrm{g} / \mathrm{ml})$ on the mean $( \pm$ s.e.m., $n=5)$ amounts of $\left[{ }^{3} \mathrm{H}\right]$ leucine incorporated into cellular and secreted proteins by Day- 7 and Day-15 guinea-pig endometrium cultured for $24 \mathrm{~h}$. *Significantly ' $P<0.05$ ) lower than the corresponding control value for the same type of protein on the same day.

15

oroteins

:d prote

1 D. $\mathrm{Cyc}$ johex. of $3 \mathrm{H}$ nea-pig f contro

ssue $/ 10$ for secreted proteins.

The outputs of PGF-2 $\alpha$ and PGE-2 from Day-15 guinea-pig endometrium, but not from myometrium cultured for $24 \mathrm{~h}$ were significantly $(P<0.01)$ reduced following the administration of intrauterine actinomycin D on Day 10. The output of 6-keto-PGF-1 $\alpha$ from the endometrium ometric Jwing a from 
Table 5. Effects of intrauterine administration of actinomycin D (Actin. D; $20 \mu \mathrm{g} /$ uterine horn) on Day 10 on mean ( \pm s.e.m., $n=10$ ) outputs of prostaglandin (PG) F-2 $\alpha$, PGE-2 and 6-keto-PGF-1 $\alpha$ (6-KF) from Day-

15 guinea-pig endometrium and myometrium cultured for $24 \mathrm{~h}$

\begin{tabular}{lccccc}
\hline & \multicolumn{5}{c}{ PG output $(\mathrm{ng} / \mathrm{mg}$ tissue $/ 24 \mathrm{~h})$} \\
\cline { 2 - 3 } & \multicolumn{2}{c}{ Endometrium } & & Myometrium \\
\cline { 2 - 3 } & Control & Actin. D & Control & Actin. D \\
\hline PGF-2 $\alpha$ & $10.40 \pm 0.60$ & $2.35 \pm 0.18^{*}$ & & $0.25 \pm 0.03$ & $0.20 \pm 0.02$ \\
PGE-2 & $0.20 \pm 0.02$ & $0.12 \pm 0.02^{*}$ & & $0.03 \pm 0.01$ & $0.05 \pm 0.01$ \\
$6-\mathrm{KF}$ & $1.51 \pm 0.08$ & $1.82 \pm 0.16$ & & $1.70 \pm 0.06$ & $2.84 \pm 0.12 \dagger$ \\
\hline
\end{tabular}

\footnotetext{
*Significantly $(P<0.01)$ lower than corresponding control value for the endometrium and for the same PG.

†Significantly $(P<0.01)$ higher than myometrial control value for $6-\mathrm{KF}$.
}

was unaffected, while 6-keto-PGF-1 $\alpha$ output from the myometrium was significantly $(P<0.01)$ increased (Table 5). Mean ( \pm s.e.m., $n=5$ ) plasma progesterone concentrations were significantly $(P<0.01)$ higher in the actinomycin D-treated guinea-pigs $(3.99 \pm 0.49 \mathrm{ng} / \mathrm{ml})$ than in the control guinea-pigs $(0 \cdot 59 \pm 0 \cdot 10 \mathrm{ng} / \mathrm{ml})$, showing that luteal regression had been prevented.

\section{Discussion}

The outputs of PGF-2 $\alpha$ and PGE-2 from guinea-pig endometrium in culture for $24 \mathrm{~h}$ were higher on Day-15 than on Day-7 of the cycle. This is not due to differences in metabolism since PG metabolism by the guinea-pig uterus is low (Poyser, 1979). There was little difference in the outputs of 6-keto-PGF-1 $\alpha$ from the endometrium between Days 7 and 15. The presence of indomethacin in the culture medium greatly inhibits the output of all 3 PGs (S. C. Riley \& N. L. Poyser, unpublished), indicating that $P G$ synthesis and secretion from guinea-pig endometrium occurs during tissue culture. During the first $6 \mathrm{~h}$ of culture, PGF-2 $\alpha$ and PGE-2 outputs were 26.5- and 4.2-fold higher, respectively, from Day-15 and from Day-7 endometrium. These results show that the preferential stimulation of endometrial PGF-2 $\alpha$ synthesis in vivo which occurs from about Day 11 , by oestradiol acting on a progesterone-primed uterus (see 'Introduction'), is maintained in tissue culture in the absence of steroids. A similar differential increase in the output of PGs between the Day7 and Day-15 guinea-pig uterus superfused in vitro was also observed, which agrees with previous results (Poyser \& Brydon, 1983).

The outputs of PGF-2 $\alpha$, PGE-2 and 6-keto-PGF-1 $\alpha$ from Day-15 endometrium and of 6-ketoPGF-1 $\alpha$ from Day-7 endometrium declined during the 24-h period of culture. The output of PGF-2 $\alpha$ from Day-7 endometrium increased during $18 \mathrm{~h}$ of culture. This stimulation may be due to the removal of the inhibitory influence of progesterone on endometrial PGF- $2 \alpha$ synthesis in the guinea-pig (Leaver \& Seawright, 1982; Riley \& Poyser, 1987a) due to the removal of the tissue from the animal. Ovariectomy of sheep on Day 12 leads to increased PGF-2 $\alpha$ release from the uterus on Day 13, an effect prevented by progesterone treatment (Vincent \& Inskeep, 1986). This study on sheep showed that progesterone does have inhibitory, as well as facilitatory, effects on PGF- $2 \alpha$ synthesis by the endometrium in vivo.

Radiolabelled leucine was incorporated at constant rates into cellular and secreted proteins by guinea-pig endometrium during $24 \mathrm{~h}$ in culture, which showed that de-novo protein synthesis occurred. The synthesis of secreted proteins, but not of cellular proteins, was greater by Day- 15 than by Day- 7 endometrium, with a $2 \cdot 8$-fold increase occurring in the amounts of secreted proteins produced after $24 \mathrm{~h}$. Actinomycin $\mathrm{D}(50 \mu \mathrm{g} / \mathrm{ml})$ inhibited the syntheses of cellular and 
secreted proteins by $72 \%$ and $46 \%$, respectively, while cycloheximide $(10 \mu \mathrm{g} / \mathrm{ml})$ and puromycin $(50 \mu \mathrm{g} / \mathrm{ml})$ both inhibited the syntheses of cellular and secreted proteins by $95 \%$ and $84 \%$, respectively.

Actinomycin D (10 and $50 \mu \mathrm{g} / \mathrm{ml}$, but not $1 \mu \mathrm{g} / \mathrm{ml}$ ), cycloheximide and puromycin (both at 10 and $50 \mu \mathrm{g} / \mathrm{ml}$ ) inhibited PGF-2 $\alpha$ output from Day-7 and Day-15 guinea-pig endometrium, although only PGF- $2 \alpha$ output from Day- 15 endometrium was inhibited during the first 6-h period of culture. Actinomycin D was less potent than the other two protein synthesis inhibitors. All three compounds generally inhibited the outputs of PGE-2 and 6-keto-PGF- $1 \alpha$, but their effects were more variable than on PGF-2 $\alpha$ output. Only actinomycin D $(50 \mu \mathrm{g} / \mathrm{ml})$ inhibited the outputs of PGE-2 and 6-keto-PGF-1 $\alpha$ from Day-15 endometrium during the first $6 \mathrm{~h}$ period of culture.

PG output from rat skeletal muscle is very rapidly inhibited (within $10 \mathrm{~min}$ ) by protein synthesis inhibitors (Turinsky, 1985; Turinsky \& Loegering, 1985; Fagan \& Goldberg, 1986). However, in the present study, none of the protein synthesis inhibitors reduced PG output from Day-7 and Day15 guinea-pig uterus when superfused over the tissue for $20 \mathrm{~min}$ in vitro. In fact, they tended to increase PG output, with cycloheximide having a marked stimulatory effect on PGE-2 output. This may explain why cycloheximide stimulated PGE-2 output from Day-7 endometrium during the first $6 \mathrm{~h}$ period of culture. The protein synthesis inhibitors do not have a very rapid inhibitory effect on PG synthesis in the guinea-pig uterus.

Previous studies have shown that the intrauterine administration of actinomycin D on Day 10 reduces the outputs of PGF-2 $\alpha$ and PGE-2, but not of 6-keto-PGF-1 $\alpha$, from the Day-15 uterus superfused in vitro, and extends oestrous cycle length due to the maintenance of the corpora lutea beyond their normal life-span as a consequence of reduced uterine PGF-2 $\alpha$ production (Poyser, 1979; Poyser \& Riley, 1987). In the present study, the intrauterine administration of actinomycin D on Day 10 reduced the outputs of PGF- $2 \alpha$ and PGE-2 on Day 15 from the endometrium, but not from the myometrium, when the tissues were cultured for $24 \mathrm{~h}$, which shows that the long-term inhibitory effect of actinomycin D on PG output from the uterus is specific to the endometrium. Furthermore, actinomycin D treatment on Day 10 had no effect on 6-keto-PGF-1 $\alpha$ output on Day I 5 from the endometrium, and stimulated output from the myometrium. The amounts of cellular and secreted proteins synthesized by Day-15 endometrium in culture following the intrauterine administration of actinomycin D on Day 10 were reduced by $65 \%$ and $50 \%$, respectively.

Since PGH synthase is destroyed during the synthesis of PGs (see Lands, 1979), the total amount of PGs synthesized by tissue homogenates (PG synthesizing ability) is indicative of the amount of PGH synthase in the tissue. The amount of PGH synthase in Day-7 and Day-15 endometrium increased 2-fold and 3-fold, respectively, during $12 \mathrm{~h}$ of culture, and these increases were inhibited by actinomycin D, cycloheximide and puromycin. None of the protein synthesis inhibitors had any effect on PGH synthase concentrations in Day-7 and Day-15 endometrium when superfused over the uterus for $20 \mathrm{~min}$ in vitro, which indicates that the inhibition of the synthesis of PGH synthase by these 3 compounds is not very rapid in onset.

Changes in endometrial PGH synthase concentrations are not the direct cause of changes in endometrial PGF-2 $\alpha$ output, for several reasons. PGF- $2 \alpha$ output from the guinea-pig uterus increases over 20-fold whereas endometrial PGH synthase concentrations increase only 2-fold between Days 7 and 15 of the cycle (Poyser \& Brydon, 1983; Poyser, 1983a). Oestradiol causes the maximum increase in endometrial PGH concentration, an effect which is reduced by progesterone (Poyser, 1983a). However, oestradiol causes only a small release of PGF-2 $\alpha$ from the guinea-pig uterus, and progesterone priming is needed for oestradiol to produce a large release of PGF- $2 \alpha$ (Poyser, 1983b). Also, in the present study, PG output from Day-15 endometrium was generally lower whereas endometrial PGH synthase concentrations were generally higher after $6 \mathrm{~h}$ of culture than after $12 \mathrm{~h}$. The increase in PGF- $2 \alpha$ output from Day-7 endometrium during culture may be connected with the increase in endometrial PGH synthase concentration, although an increase in enzyme concentration cannot be the sole cause since endometrial 6-keto-PGF-1 $\alpha$ output fell during the culture period. Therefore, the supply of substrate (i.e. arachidonic acid), and not changes in 
PGH synthase concentration, is the rate-limiting step in endometrial PG synthesis. However, the supply of arachidonic acid is not dependent upon changes in the endometrial concentration of phospholipase (PL) A-2, since the amounts of PLA-2 in the guinea-pig endometrium are more than sufficient to account for the amounts of PGF-2 $\alpha$ synthesized on Days 7 and 15 of the cycle (Downing \& Poyser, 1983).

Previous studies have indicated that oestradiol, acting on a progesterone-primed uterus, activates PLA-2 to release arachidonic acid, from phosphatidylcholine and phosphatidylethanolamine, which from Day 11 of the cycle is preferentially directed into the PGF- $2 \alpha$-forming pathway (Leaver \& Poyser, 1981; Downing \& Poyser, 1983; Ning et al., 1983; Poyser, 1983b, 1987; Ning \& Poyser, 1984). This stimulation of endometrial PGF-2 $\alpha$ synthesis requires intracellular and extracellular $\mathrm{Ca}^{2+}$ (Riley \& Poyser, 1987b), but is not dependent upon activation of the phosphatidylinositol (PI) cycle (Ning \& Poyser, 1984). The present study indicates that endometrial PGF-2 $\alpha$ synthesis in the guinea-pig is also dependent upon protein synthesis, and this is consistent with a previous suggestion (Poyser, 1984) that "oestradiol stimulates the synthesis in the endometrium of a calcium-mobilizing protein which, on a uterus primed with progesterone, causes the influx of extracellular $\mathrm{Ca}^{2+}$ and/or release of intracellular $\mathrm{Ca}^{2+}$. The increase in intracellular $\mathrm{Ca}^{2+}$ concentration then activates PLA-2, possibly via an interaction with calmodulin (Poyser, 1985a, b; Riley \& Poyser, 1987b). Since protein synthesis inhibitors inhibit endometrial PG output on Days 7 and 15 , it would appear that the synthesis of such a protein occurs throughout the cycle and that its synthesis is stimulated following the increased release of oestradiol from the ovary after Day 10 (Joshi et al., 1973). However, only from Day 11 is the arachidonic acid released directed into the PGF-2 $\alpha$-forming pathway.

The intrauterine administration of actinomycin $D$ in sheep inhibits regression of the corpus luteum (French \& Casida, 1973), indicating that endometrial PGF-2 $\alpha$ production in the sheep is also dependent upon protein synthesis. Actinomycin $\mathbf{D}$ and cycloheximide administered systemically to ovariectomized rats did not prevent the stimulation of uterine PG synthesis by oestradiol (Castracane \& Jordan, 1976). However, actinomycin D administered systemically to guinea-pigs failed to affect uterine PG synthesis (Poyser, 1979), so the study on rats needs repeating but with the protein synthesis inhibitors being administered by the intrauterine route. Actinomycin $D$ also failed to prevent the stimulation by oestradiol of PG synthesis by human endometrial, epithelial cells in culture (Smith \& Kelly, 1987). However, it was not established that the concentrations of actinomycin D used $(1-100 \mathrm{ng} / \mathrm{ml})$ inhibited protein synthesis, and they are much lower than the concentrations $(>1 \mu \mathrm{g} / \mathrm{ml})$ required in the present study to inhibit endometrial prostaglandin and protein syntheses. A more detailed study on the effects of protein synthesis inhibitors on PG synthesis and protein synthesis in the human endometrium is required. Prostaglandin synthesis by fibroblasts, skeletal muscle, macrophages, brain, and vascular endothelial cells is dependent upon protein synthesis (Pong et al., 1977; Bonney et al., 1980; Townsend et al., 1984; Turinsky, 1985; Clark et al., 1986). A protein of $M_{\mathrm{r}} 28000$, which activates PLA-2 and is involved in the stimulation of PG synthesis, has been isolated from vascular endothelial cells (Clark et al., 1987, 1988). Whether this protein is present in the endometrium and is responsible for the stimulation of endometrial PGF- $2 \alpha$ synthesis requires further study.

This study was supported by grants from the SERC and MRC, and by a MRC Research Studentship to SCR. We thank Miss L. Marshall for technical assistance; and the Upjohn Co., Kalamazoo, Michigan, USA, for authentic PGs.

\section{References}

Antonini, R., Turner, T.T. \& Pauerstein, C.J. (1976)

The hormonal control of the guinea-pig corpus luteum during early pregnancy. Fert. Steril. 27, 1322-1325.
Blatchley, F.R. \& Poyser, N.L. (1974) The effect of oestrogen and progesterone on the release of prostaglandins from the uterus of the ovariectomised guineapig. J. Reprod. Fert. 40, 205-209. 
Blatchley, F.R., Donovan, B.T., Horton, E.W. \& Poyser, N.L. (1972) The release of prostaglandins and progestin into the utero-ovarian venous blood of guinea-pigs during the oestrous cycle and following oestrogen treatment. J. Physiol., Lond. 222, 69-88.

Bonney, R.J., Wightman, P.D., Dahlgren, M.E., Davies, P., Kuehl, F.A. Jr. \& Humes, J.L. (1980) Effect of RNA and protein synthesis inhibitors on the release of inflammatory mediators by macrophages responding to phorbol myristate acetate. Biochem. Biophys. Acta 633, $410-421$.

Brenner, R.M. \& West, N.B. (1975) Hormonal regulation of the reproductive tract in female mammals. Ann. Rev. Physiol. 37, 273-302.

Castracane, V.D. \& Jordan, V.C. (1976) Considerations into the mechanisms of estrogen stimulated uterine prostaglandin synthesis. Prostaglandins 12, 243-251.

Clark, M.A., Littlejohn, D., Mong, S. \& Crooke, S.T. (1986) Effect of leukotrienes, bradykinin and calcium ionophore (A23187) on bovine endothelial cells: release of prostacyclin. Prostaglandins 31, 157-166.

Clark, M.A., Conway, T.M., Shorr, R.G.L. \& Crooke, S.T. (1987) Identification and isolation of a mammalian protein which is antigenically and functionally related to the phospholipase $\mathrm{A}_{2}$ stimulating peptide mellitin. J. biol. Chem. 262, $4402-4407$.

Clark, M.A., Chen, M.-J., Crooke, S.T. \& Bomalalaski, J.S. (1988) Tumour necrosis factor (cachetin) induces phospholipase $\mathrm{A}_{2}$ activity and synthesis of a phospholipase $\mathbf{A}_{\mathbf{2}}$-activating protein in endothelial cells. Biochem. J. 250, 125-132.

Dighe, K.K., Emslie, H.A., Henderson, L.K., Rutherford, F. \& Simon, L. (1975) The development of antisera to prostaglandins $\mathrm{B}_{2}$ and $\mathrm{F}_{2 a}$ and their analysis using solid-phase and double antibody radioimmunoassay methods. Br. J. Pharmac. 55, 503-514.

Downing, I. \& Poyser, N.L. (1983) Estimation of phospholipase $\mathrm{A}_{2}$ activity in guinea-pig endometrium on days 7 and 16 of the estrous cycle. Prostaglandins, Leuk. and Med. 12, 107-117.

Earthy, M., Bishop, C. \& Flack, J.D. (1975) Progesterone and prostaglandin $\mathbf{F}$ concentrations in utero-ovarian venous plasma of cyclic guinea-pigs. $J$. Endocr. 64, $11 P-12 P$, Abstr.

Fagan, J.M. \& Goldberg, A.L. (1986) Inhibitors of protein and RNA synthesis cause a rapid block in prostaglandin production at the prostaglandin synthase step. Proc. natn. Acad. Sci. U.S.A. 83, 2771-2775.

Findlay, J.K., Ackland, N., Burton, R.D., Davis, A.J., Maule Walker, F.M., Walters, D.E. \& Heap, R.B. (1981) Protein, prostaglandin and steroid synthesis in caruncular and inter-caruncular endometrium of sheep before implantation. J. Reprod. Fert. 62, 361 377.

French, L.R. \& Casida, L.E. (1973) Effect of actinomycin on corpus luteum regression in ewes. J. Anim. Sci. 37, 1218-1221.

Horton, E.W. \& Poyser, N.L. (1976) Uterine luteolytic hormone: a physiological role for prostaglandin $\mathbf{F}_{2 a}$. Physiol. Rev. 56, 595-651.

Johsi, H.S., Watson, D.J. \& Labhsetwar, A.P. (1973) Ovarian secretion of oestradiol, oestrone, 20-dihydroprogesterone and progesterone during the oestrous cycle. J. Reprod. Fert. 35, 177-182.
Lands, W.E.M. (1979) The biosynthesis and metabolism of prostaglandins. Ann. Rev. Physiol. 41, 633-652.

Leaver, H.A. \& Poyser, N.L. (1981) Distribution of arachidonic acid and other fatty acids in the lipids of guinea-pig uterus and plasma in relation to uterine prostaglandin synthesis. J. Reprod. Fert. 61, $265-271$.

Leaver, H.A. \& Seawright, A. (1982) Control of endometrial prostaglandin output in vitro during the estrous cycle of the guinea-pig: influence of estradiol-17 $\beta$, progesterone, oxytocin and calcium ionophore A23187. Prostaglandins, Leuk. and Med. 9, 657-668.

Lytton, F.D.C. \& Poyser, N.L. (1982) Concentration of PGF- $2 \alpha$ and PGE-2 in the uterine venous blood of rabbits during pseudopregnancy and pregnancy. $J$. Reprod. Fert. 64, 621-629.

Mitchell, S., Poyser, N.L. \& Wilson, N.H. (1977) Effect of p-bromophenancyl bromide, an inhibitor of phospholipase $A_{2}$, on arachidonic acid release and prostaglandin synthesis by the guinea-pig uterus. $\mathrm{Br}$. J. Pharmac. 59, 107-113.

Ning, A.C.W.S. \& Poyser, N.L. (1984) Further studies on the control of arachidonic acid turnover in guinea-pig endometrium in relation to prostaglandin production. Prostaglandins, Leuk. and Med. 16, 285302.

Ning, A.C.W.S., Leaver, H.A. \& Poyser, N.L. (1983) Arachidonic acid uptake into and release from guinea-pig endometrium in vitro on days 7 and 15 of the oestrous cycle. Prostaglandins, Leuk, and Med. 10, 369-380.

Pong, S.-S., Hong, S.-C.L. \& Levine, L. (1977) Prostaglandin production by methylcholanthrene-transformed mouse BALB/3T3. J. biol. Chem. 252, $657-668$.

Poyser, N.L. (1979) Effect of actinomycin D on uterine prostaglandin production and oestrous cycle length in guinea-pigs. J. Reprod. Fert. 56, 559-565.

Poyser, N.L. (1980) Development and use of radioimmunoassay for measuring 6-oxo-prostaglandin $\mathrm{F}_{1 \alpha}$. In Prostaglandins, Prostacyclin and Thromboxane Measurement, pp. 44-55. Eds J. M. Boeynaems \& A. G. Herman. Martinus Nijhoff, The Hague.

Poyser, N.L. (1981) Prostaglandins in Reproduction. John Wiley and Sons Ltd, Chichester.

Poyser, N.L. (1983a) Differential stimulation of prostaglandin and thromboxane synthesizing capacities in the guinea-pig uterus and ovary. Prostaglandins, Leuk. and Med. 10, 162-177.

Poyser, N.L. (1983b) Effect of treating ovariectomized guinea-pigs with estradiol and progesterone on basal and A23187-stimulated release of prostaglandins from the uterus superfused in vitro. Prostaglandins, Leuk and Med. 11, 345-360.

Poyser, N.L. (1984) Prostaglandin production by the early pregnant guinea-pig uterus in relation to implantation and luteal maintenance, and the effect of estradiol. J. Reprod. Fert. 72, 117-127.

Poyser, N.L. (1985a) Effect of trifluoperazine, a calmodulin antagonist, on prostagladin output from the guinea-pig uterus. J. Reprod. Fert. 73, 295-303.

Poyser, N.L. (1985b) Effects of TMB-8, an intracellular calcium antagonist, and $\mathrm{W}-7$, a calmodulin antagonist, on prostaglandin output from the guinea-pig uterus. J. Reprod. Fert. 75, 223-230. 
Poyser, N.L. (1987) Effects of various factors on prostaglandin synthesis by the guinea-pig uterus. $J$. Reprod. Fert. 81, 269-276.

Poyser, N.L. \& Brydon, L.J. (1983) Prostaglandin release from the guinea-pig uterus superfused in vitro. Effect of stage of estrous cycle, progesterone, estradiol, oxytocin and A23187. Prostaglandins 25, 443-456.

Poyser, N.L. \& Horton, E.W. (1975) Plasma progesterone levels in guinea-pigs actively immunised against prostaglandin $\mathrm{F}_{2 \alpha}$, hysterectomized or treated with intrauterine indomethacin. J. Endocr. 67, 81-88.

Poyser, N.L. \& Riley, S.C. (1987) Effect of actinomycin $\mathrm{D}$ on prostaglandin synthesis by and output from the guinea-pig uterus. Prostaglandins, Leuk. and Med. 28, 153-168.

Poyser, N.L. \& Scott, F.M. (1980) Prostaglandin and thromboxane production by the rat uterus and ovary in vitro during the oestrous cycle. J. Reprod. Fert. 60, $33-40$.

Riley, S.C. \& Poyser, N.L. (1987a) Effects of oestradiol, progesterone, hydrocortisone and oxytocin on prostaglandin output from the guinea-pig endometrium maintained in tissue culture. Prostaglandins 34, 535-552.

Riley, S.C. \& Poyser, N.L. (1987b) Prostaglandin production by the guinea-pig endometrium: is calcium necessary? J. Endocr. 113, 463-471.
Smith, S.K. \& Kelly, R.W. (1987) The effect of oestradiol-17 $\beta$ and actinomycin $D$ on the release of PGF and PGE from separated cells of human endometrium. Prostaglandins 34, 553-561.

Strinden, S.T. \& Shapiro, S.S. (1983) Progesteronealtered secretory proteins from cultured human endometrium. Endocrinology 112, 862-870.

Townsend, Y., Cranston, W.I. \& Hellon, R.F. (1984) Inhibition of brain protein synthesis suppresses the release of prostaglandin $\mathrm{E}_{2}$ in febrile rabbits. Brain Res. Bull. 13, 335-348.

Turinsky, J. (1985) Inhibitors of protein synthesis, puromycin and emetine, inhibit prostaglandin $\mathrm{E}_{2}$ release by skeletal muscle. Biochim. Biophys. Acta $\mathbf{8 4 0 , 1 3 4}$ 137.

Turinsky, J. \& Loegering, D.J. (1985) Prostaglandin $\mathrm{E}_{2}$ and muscle protein turnover in Pseudomonas aeruginosia sepsis. Biochim. Biophys. Acta $\mathbf{8 4 0}$, 137-140.

Vincent, D.L. \& Inskeep, E.K. (1986) Role of progesterone in regulating utero-ovarian venous concentrations of $\mathrm{PGF}_{2 \mathrm{a}}$ and $\mathrm{PGE}_{2}$ during the estrous cycle and early pregnancy in ewes. Prostaglandins 31, 715724.

Received 1 July 1988 